RESEARCH ARTICLE

\title{
Identification of a robust protocol for isolating PCR amenable DNA from caryopses to employ DNA fingerprinting to claim the plant breeders' rights and varietal ownership of the exporting rice bulks
}

\author{
G.K.S. Ananda ${ }^{1, *}$, W.W.M.U.K. Wijesundara ${ }^{1}$, U.A.K.S. Udawela ${ }^{2}$ and S.D.S.S. Sooriyapathirana ${ }^{1}$
}

\author{
${ }^{I}$ Department of Molecular Biology and Biotechnology, Faculty of Science, University of Peradeniya, Peradeniya, Sri \\ Lanka \\ ${ }^{2}$ Rice Research and Development Institute (RRDI), Bathalagoda, Ibbagamuwa, Sri Lanka
}

Received:16/03/2018; Accepted:24/04/2018

\begin{abstract}
Rice Research and Development Institute (RRDI) at Bathalagoda and its' substations are solely conducting rice breeding in Sri Lanka. Recently, RRDI has identified five exportable rice varieties/lines. As rice export in Sri Lanka is undertaken by the private sector, the RRDI does not receive any foreign revenues or credit for breeding rice genotypes. Therefore, RRDI currently is in need of a reliable protocol to claim the Plant Breeders' Rights (PBR) of these exportable genotypes. The first step of establishing such a protocol based on DNA fingerprinting is depending on the ability to extract good quality DNA from rice caryopses. Therefore, the present study compared the suitability of commonly available DNA extraction methods to purify DNA from rice caryopsis. Three rice genotypes; $\mathrm{Bg} 250$ and At 353 (varieties for local consumption) and Bw-Bs-1-2-31 (with export potential) were selected. Three parboiled rice samples each from long- and short-grain groups were also selected. The DNA extraction, quantification and purity assessment were carried out using four methods viz., CTAB, modified CTAB, Promega kit and Qiagen kit. The extracted DNA was subjected to simplex and multiplex PCR using four rice specific DNA markers. Although positive PCR bands were obtained for all four methods, the modified CTAB method yielded the significantly highest DNA yield $(6196.67 \mu \mathrm{g} / \mathrm{ml})$ compared to other methods. Thus, RRDI can employ modified CTAB method in the protocol to claim its PBR and rice varietal ownerships.
\end{abstract}

Keywords: Plant Breeders' Rights (PBR); Rice Varietal Authenticity; DNA extraction from rice grains; modified CTAB method for rice grains; exporting rice in Sri Lanka.

\section{INTRODUCTION}

Rice (Oryza sativa L.) is the staple food for more than half of the world population (Muthayya et al., 2012). Rice is the primary food of Sri Lankans and considered as the major crop in the country occupying $34 \%$ of the total cultivable lands (RRDI, 2018). Sri Lankan rice farming is depending on the improved varieties released by the breeding programs at the Rice Research and Development Institute (RRDI), Bathalagoda (Bg) and its substations located at Ambalanthota (At) Bombuwala (Bw) and Labuduwa (Ld). A total of 84 improved rice varieties have been released by the Department of Agriculture (DOA), Sri Lanka so far following expensive and tedious breeding programs. Although these varieties were named using a specific number proceeded by the abbreviations to indicate the location $(\mathrm{Bg}$, At and $\mathrm{Bw})$, there are no comprehensive protocols available to detect and claim the varietal ownership to the DOA. The $\mathrm{Bg}$, At and $\mathrm{Bw}$ varieties are legally belonged to RRDI, Sri Lanka. The DOA holds the Plant Breeders' Rights (PBR) for these varieties based on the distinctiveness, uniformity and stability (DUS) testing (Pourabed et al., 2015). These rice varieties are merely grown for the local consumption. Recently, three varieties; At 362, Bg 94-1, Bg 360 and two lines Bg 1165-2 and BwBs-1-2-31 have been identified as the rice genotypes with potential for export market. Currently, At 362, Bg 94-1 and $\mathrm{Bg} 360$ rice varieties are grown by some farmers for export purposes with the help of the private companies. Although DOA holds the PBR for these varieties, there is no accurate molecular biological procedure available to claim the breeders' ownership. The breeders' ownership of these exportable rice varieties is important in order to acquire certain percentage of the profit earned by exporters to the DOA to be used in research and developmental activities. Since the breeding programs at RRDI are conducted using limited funds provided by Sri Lankan government, the breeders are facing a mountainous task to carry out large scale breeding programs and to employ novel molecular techniques such as Marker Assisted Selection (MAS) and DNA sequence analysis to expedite the breeding processes and to produce more efficient rice varieties. Gaining profits from foreign revenue earned through exports from improved plant varieties is common with other crops such as tea, rubber, coconut, sugar cane and spices (Disna, 2017). If such a system can be established for the export market of Sri Lankan rice varieties, the rice breeding programs can be conducted without solely depend on the financial assistance from the government.

In the export market, the PBR cannot be claimed just by assessing the morphometric traits of seeds belonging to different rice varieties (Li et al., 2014). In order to establish 
a protocol based on DNA fingerprinting, it is vital to use DNA samples extracted from rice caryopses of market samples (caryopsis is the edible part of the rice grain). The DNA fingerprinting protocols for authentication of seeds, fruits and other plant parts of the improved varieties are common for crops such as cereals (Oryza spp., Zea mays and Triticum spp.), pulses (Pisum sativum, Phaseolus spp. and Vigna spp.), vegetables (Capsicum spp. andSolanum spp.) fruits (Mangifera indica, Citrus spp. and Musa spp.) and sugar producing plants (Saccharum spp. and Beta spp.) (Bhat, 2001). However, such protocols are not available for rice in Sri Lanka. To establish such a protocol, it is important to extract good quality DNA samples that can be amplified with PCR using microsatellite markers. However, few studies are available for extracting PCR amenable DNA from rice grains. Due to the presence of high amount of starch and the metabolically less-active stage of the rice caryopses, the DNA extraction is often difficult (Kasem et al., 2008). As a result of the presence of PCR inhibitors such as tannins and polyphenols, the efficiency of PCR based advanced molecular techniques such as DNA fingerprinting and MAS would be challenging for rice (Sarwat et al., 2006). Few studies have been published on the extraction of the DNA samples from the cereal grains (Kang et al., 1998; Xin et al., 2003), though direct protocols are available in the literature to extract DNA from rice caryopsis. Therefore, the objective of the present study was to document the suitability of commonly known DNA extraction methods to isolate DNA from rice caryopses with the aim of used in PCR based DNA fingerprinting with microsatellite markers to claim the PBR and the varietal authenticity.

\section{MATERIALS AND METHODS}

\section{Plant Material}

Grains from three rice varieties namely $\mathrm{Bg} 250$, BwBs-1-2-31 andAt 353 were subjected to the DNA extraction. The rice grains were de-hulled to obtain caryopses. A sample of $10 \mathrm{~g}$ of the caryopses from each variety was ground using a mortar and pestle at room temperature until a fine powder was obtained. Additionally, DNA was extracted from six other market samples of parboiled rice [three long grain (LG) (Nadu) and three short grain (SG) $(S a m b a)]$ for the purpose of validating the DNA extraction protocol selected at the end.

\section{DNA extraction}

DNA was extracted from all ground rice caryopsis samples using four commonly available extraction methods viz., cetyl trimethylammonium bromide (CTAB) extraction (Doyle and Doyle, 1990), modified CTAB extraction (Mutou et al., 2014) and commercially available Wizard ${ }^{\circledR}$ Genomic DNA Purification (Cat. No.: A1120, www. worldwide.promega.com) (Promega Kit) and Qiagen DNeasy Plant Mini (Cat. No.: 69104, www.qiagen.com) (Qiagen Kit) Kits. The extracted DNA was stored at $-20^{\circ} \mathrm{C}$. The quality of the DNA was visualized on $1 \%$ agarose gel electrophoresis and the concentrations and purities of the DNA samples were measured using the UV absorbance at $260 \mathrm{~nm}$ (A260) and $280 \mathrm{~nm}$ (A280). The concentration and purity of the DNA samples were calculated using the following equations (Sambrook and Russell, 2001). The data was analyzed using the analysis of variance (ANOVA) in the statistical package SAS 9.4 (SAS Institute Inc., Cary, NC, USA).

DNA concentration $=50 \mu \mathrm{g} / \mathrm{ml} \times \mathrm{A} 260 \times$ dilution factor Purity of DNA sample $=\frac{\mathrm{A} 260}{\mathrm{~A} 280}$

\section{CTAB method}

Approximately $1 \mathrm{~g}$ of ground rice caryopses was measured into an eppendorf tube and $750 \mu 1$ of extraction buffer $[4 \%$ CTAB, 10mM Tris- $\mathrm{HCl}$ (pH 8.0), 20mM EDTA and 1.4M $\mathrm{NaCl}$ ] was added. The mixture was incubated in a water bath at $60^{\circ} \mathrm{C}$ for 30 min with periodic mixing by gently inverting the tube in every $10 \mathrm{~min}$. After incubation, one volume of choloform/isoamyl alcohol (24:1) was added and mixed using a vortex. The mixture was centrifuged at $7000 \mathrm{rpm}$ for $10 \mathrm{mins}$. The supernatant was transferred into a clean sterile eppendorf tube and 0.6 volume of icecold isopropanol was added and the contents were mixed by inverting the tube several times. The mixture was then incubated at $-80^{\circ} \mathrm{C}$ for 15 mins and then centrifuged at 7000 rpm for 10 mins to obtain the pellet and the supernatant was discarded. Next, the pellet was washed by adding 1.5 $\mathrm{ml}$ of washing solution containing $70 \%$ ethanol and $10 \mathrm{mM}$ ammonium acetate and the mixture was centrifuged at 7000 rpm for 10 mins at $4^{\circ} \mathrm{C}$. The supernatant was discarded and the previous step was repeated for further washing. Finally, the pellet was completely air dried and $30 \mu \mathrm{l}$ of TE buffer [10ml of $1 \mathrm{M}$ Tris-HCl (pH 8.0) and $1 \mathrm{mM}$ EDTA] was added to dissolve the DNA.

\section{Modified CTAB method}

The modified CTAB extraction method described in Mutou et al. (2014) was used to extract DNA from $1 \mathrm{~g}$ of ground rice caryopses. The following specific modifications were made in the above explained CTAB extraction method. The modified CTAB extraction buffer containing $4 \% \mathrm{CTAB}$, $10 \mathrm{ml}$ of $2 \mathrm{M}$ Tris- $\mathrm{HCl}(\mathrm{pH} 8.0), 8 \mathrm{ml}$ of $0.5 \mathrm{M}$ EDTA, $1.4 \mathrm{MNaCl}$ and $2 \mathrm{~g}$ of Polyvinylpyrrolidone (PVP) in 200 $\mathrm{ml}$ of total volume was used for the extraction. The mixture was centrifuged at $12,000 \mathrm{rpm}$ for $10 \mathrm{mins}$. In place of 0.6 volume of ice-cold isopropanol, in this modified CTAB method, $300 \mu \mathrm{l}$ of isopropanol at room temperature and $50 \mu \mathrm{l}$ of $3 \mathrm{M} \mathrm{Na}$-actaete were added and incubated on ice for $30 \mathrm{~s}$ min to precipitate the DNA. Finally, $30 \mu \mathrm{l}$ of TE and RNase (10 mg RNase in $1 \mathrm{ml}$ of TE buffer) were added and incubated at $60^{\circ} \mathrm{C}$ to dissolve DNA.

\section{DNA extraction from parboiled rice}

DNA was extracted from six parboiled rice samples collected from the open market in Sri Lanka using the modified CTAB method.

\section{PCR}

PCR to check the amplification of DNA to obtain bands was carried out using an agarose based Pupl [a qualitative trait locus (QTL) in rice genome associated with the trait 
Table 1: The markers used for PCR-based DNA fingerprinting.

\begin{tabular}{|c|c|c|c|}
\hline Marker & Primer sequence (Forward, Reverse) & Ta $\left({ }^{0} \mathbf{C}\right)$ & Reference \\
\hline$K 20$ & $\begin{array}{l}\text { 5'TCAGGTGATGGGAATCATTG3', } \\
\text { 5'TGTTCCAACCAAACAACCTG3' }\end{array}$ & & Chin et al., (2010) \\
\hline RM336 & $\begin{array}{l}\text { 5'CTTACAGAGAAACGGCATCG3', } \\
\text { 5'GCTGGTTTGTTTCAGGTTCG3' }\end{array}$ & 55 & Temnykh et al., (2000) \\
\hline RM472 & $\begin{array}{l}\text { 5'CCATGGCCTGAGAGAGAGAG3', } \\
\text { 5'AGCTAAATGGCCATACGGTG3' }\end{array}$ & & Selvaraj et al., (2011) \\
\hline RM493 & $\begin{array}{l}\text { 5'TAGCTCCAACAGGATCGACC3', } \\
\text { 5'GTACGTAAACGCGGAAGGTG3' }\end{array}$ & & Senguttuvel et al.,(2010) \\
\hline
\end{tabular}

Table 2: DNA yield and purity of the samples extracted using four different methods/kits.

\begin{tabular}{|c|c|c|c|c|c|}
\hline Method/kit & Variety/line & Mean DNA yield $(\mu \mathrm{g} / \mathrm{ml})$ & Mean DNA yield $(\mu \mathrm{g} / \mathrm{ml})$ & Mean purity & Mean purity \\
\hline \multirow{3}{*}{ CTAB } & $\operatorname{Bg} 250$ & $1034.67^{f}$ & \multirow{3}{*}{$2340.33^{b}$} & $1.62^{\mathrm{a}}$ & \multirow{3}{*}{$1.71^{\mathrm{b}}$} \\
\hline & Bw-Bs-1-2-31 & $3674.67^{\mathrm{d}}$ & & $1.77^{\mathrm{a}}$ & \\
\hline & At 353 & $2311.67^{\mathrm{e}}$ & & $1.73^{\mathrm{a}}$ & \\
\hline \multirow{3}{*}{$\begin{array}{l}\text { Modified } \\
\text { CTAB }\end{array}$} & Bg 250 & $7586.33^{\mathrm{a}}$ & \multirow{3}{*}{$6196.67^{\mathrm{a}}$} & $1.53^{\mathrm{a}}$ & \multirow{3}{*}{$1.55^{\mathrm{c}}$} \\
\hline & Bw-Bs-1-2-31 & $6317.33^{\mathrm{b}}$ & & $1.54^{\mathrm{a}}$ & \\
\hline & At 353 & $4686.33^{c}$ & & $1.59^{\mathrm{a}}$ & \\
\hline \multirow{3}{*}{ Promega } & Bg 250 & $328.33^{\mathrm{f}}$ & \multirow{3}{*}{$775.11^{\mathrm{c}}$} & $1.36^{\circ}$ & \multirow{3}{*}{$1.32^{\mathrm{d}}$} \\
\hline & Bw-Bs-1-2-31 & $600.67^{\mathrm{f}}$ & & $1.33^{\mathrm{b}}$ & \\
\hline & At 353 & $1396.33^{\mathrm{f}}$ & & $1.25^{\mathrm{b}}$ & \\
\hline \multirow{3}{*}{ Qiagen } & Bg 250 & $174.00^{\mathrm{f}}$ & \multirow{3}{*}{$221.44^{\mathrm{d}}$} & $1.87^{\mathrm{a}}$ & \multirow{3}{*}{$1.84^{\mathrm{a}}$} \\
\hline & Bw-Bs-1-2-31 & $361.33^{\mathrm{f}}$ & & $1.81^{\mathrm{a}}$ & \\
\hline & At 353 & $129.00^{\mathrm{f}}$ & & $1.82^{\mathrm{a}}$ & \\
\hline
\end{tabular}

Means denoted by same letters within columns are not significant different at $\mathrm{P}<0.05$.

phosphorous uptake) linked monomorphic DNA marker, K20 (Chin et al., 2010), and three microsatellite markers namely $R M 336, R M 472$ and $R M 493$. The forward and reverse primer sequences for these markers are given in Table 1. The PCR amplification was done by using $1.5 \mu \mathrm{l}$ template DNA in $15 \mu$ l reaction using $2 \times$ GoTaq Green ${ }^{\circledR}$ Master Mix (pH 8.5) (Cat. No: M7122,www.worldwide. promega.com). The reaction mixture comprised of $7.5 \mu \mathrm{l}$ of Master Mix, $0.5 \mu \mathrm{l}$ of $10 \mu \mathrm{M}$ of each primer, nuclease free water and $90 \mathrm{ng}$ of template DNA. The amplification was performed in a thermal cycler (Model No.: TP600, TAKARA BIO Inc., Otsu, Shiga, Japan) using 5 min initial denaturation at $94^{\circ} \mathrm{C}$, followed by 35 cycles of 30 secs of denaturation at $94^{\circ} \mathrm{C}, 1 \mathrm{~min}$ at annealing temperature (Ta) of $55^{\circ} \mathrm{C}, 2 \mathrm{~min}$ at $72^{\circ} \mathrm{C}$ and final extension at $72^{\circ} \mathrm{C}$ for 10 min. The simplex PCR was carried out for markers $R M 472$ and $R M 493$ separately and the multiplex PCR was carried out with the markers $K 20$ and $R M 336$. In each PCR, rice leaf DNA and no-template were used as the positive and negative controls respectively. The PCR products were subjected to ethidium bromide stained 2.5\% agarose gel electrophoresis.

\section{RESULTS}

\section{Yield and purity of extracted DNA}

Significantly variable DNA quantities were resulted when
$1 \mathrm{~g}$ of ground caryopses of the three rice varieties were subjected to DNA extraction using CTAB extraction method, modified CTAB extraction method, Promega kit and Qiagen kit. The highest mean DNA yield was obtained for the rice variety $\mathrm{Bg} 250$ when extracted using modified CTAB method $(7586.3 \mu \mathrm{g} / \mathrm{ml})$. When the DNA yield of the samples extracted from all three varieties combined separately for each of the four DNA extraction methods/ kits, the highest mean DNA yield was obtained for modified CTAB method $(6196.7 \mu \mathrm{g} / \mathrm{ml})$, followed by CTAB method $(2340.3 \mu \mathrm{g} / \mathrm{ml})$, Promega kit $(775.1 \mu \mathrm{g} / \mathrm{ml})$ and the least mean DNA yield was observed for Qiagen kit $(221.4 \mu \mathrm{g} /$ $\mathrm{ml})(P<0.05)$. When the purity of DNA was calculated for each variety/line and each method/kit separately, the mean purity levels were observed in the range of 1.25 1.87. When DNA purities of the four different extraction methods were compared, significantly highest DNA purity was observed for Qiagen kit (1.84) followed by CTAB method (1.71) (Table 2). The mean purity of the DNA samples extracted using modified CTAB method was 1.55 and the least purity of 1.32 was observed for Promega kit $(P<0.05)$. The DNA purity of 1.80 is generally considered as the standard highest purity for DNA samples, (Kasem et al., 2008) thus the Qiagen kit can be considered as the best method for extracting pure DNA samples compared to the other three methods/kit. The agarose gel images of the genomic DNA extracted from all three varieties/lines 


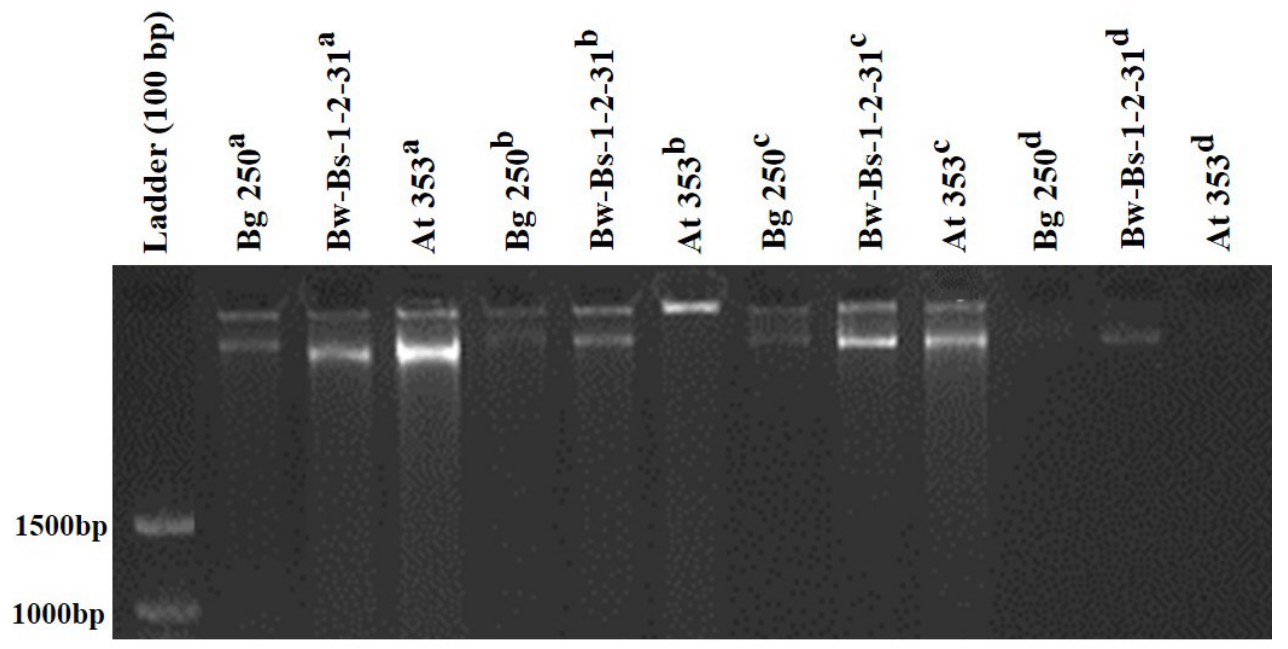

Figure 1: The agarosegel image of the genomic DNA extracted using four different methods/kits (1\% agarose gel electrophoresis). Names of the rice varieties/lines are given on the top. A 100bp ladder was used in gel electrophoresis. a: CTAB method, b: modified CTAB method, c: Promega kit, d: Qiagen kit.

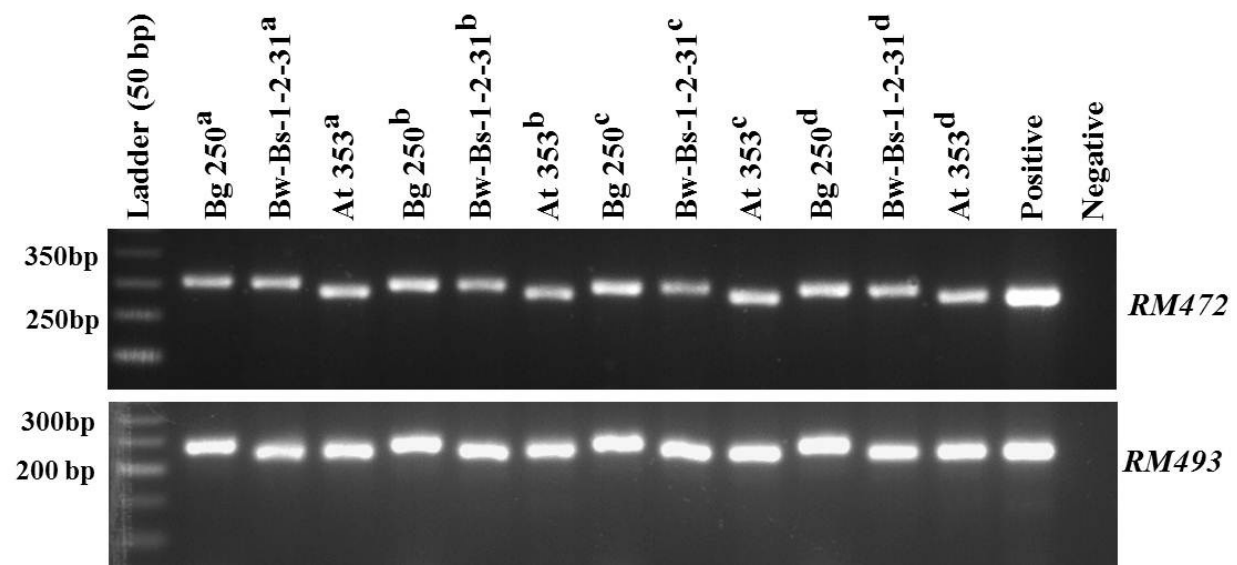

Figure 2: Composite agarose gel image of the simplex PCR for $R M 472$ and $R M 493$ markers (2.5\% agarose gel electrophoresis). The names of the microsatellite markers are indicated on the right side of the Figure and the key band sizes of the ladder are indicated on the left side. The 50bp ladder was used as the size standard. Names of the rice varieties/lines are given on the top. a: CTAB method, b: modified CTAB method, c: Promega kit, d: Qiagen kit.

using four methods/kits are given in Figure 1. According to the genomic DNA bands and smears observed on the gel, higher concentrations were observed in CTAB method, modified CTAB method and Promega kit. Based on the smears on the gel, partial degradation of the DNA samples was observed for CTAB method and Promega kit than the other two.

\section{PCR}

The extracted DNA samples of the three varieties/lines using four extraction methods/kits were subjected to simplex PCR using the microsatellite markers RM472 and RM493. Regardless of the significantly variable DNA concentrations (Table 2), a clear amplification was observed for both microsatellite markers. For $R M 472, \mathrm{Bg}$ 250 and Bw-Bs-1-2-31 yielded the same band (300bp) and At 353 yielded a slightly shorter band (280bp) whereas for RM493, Bw-Bs-1-2-31 and At 353 yielded the same band (235bp) and $\mathrm{Bg} 250$ yielded a slightly longer band (245bp). For both markers, the band intensities of the PCR amplified DNA samples from the caryopsis were having the same intensity compared to the band obtained for rice leaf DNA which was used as the positive control in this study (Figure 2).

All the DNA samples yielded two expected bands in the multiplex PCR with K20 and RM336 markers (Figure 3). However, the monomorphic band of $245 \mathrm{bp}$ for $K 20$ marker was less intense compared to the two polymorphic bands obtained for $R M 336$. The marker $R M 336$ yielded a band of $155 \mathrm{bp}$ for varieties $\mathrm{Bg} 250$ and At 353 whereas a band of 200bp for the line Bw-Bs-1-2-31.

When the DNA extracted from the market samples using the modified CTAB method were subjected to simplex PCR, all the samples yielded the expected bands of 230bp and 290bp for RM472 and RM493 microsatellite markers respectively. However, the band intensities for the DNA samples extracted from caryopsis were less intense compared to the band intensities obtained for rice leaf DNA which was used as the positive control (Figure 4). In the multiplex PCR, all the DNA samples extracted from market samples yielded the expected bands for $K 20$ (245bp) and $R M 336$ (145bp). The band intensities were similar to the positive controls (leaf DNA from rice varieties) (Figure 5). 


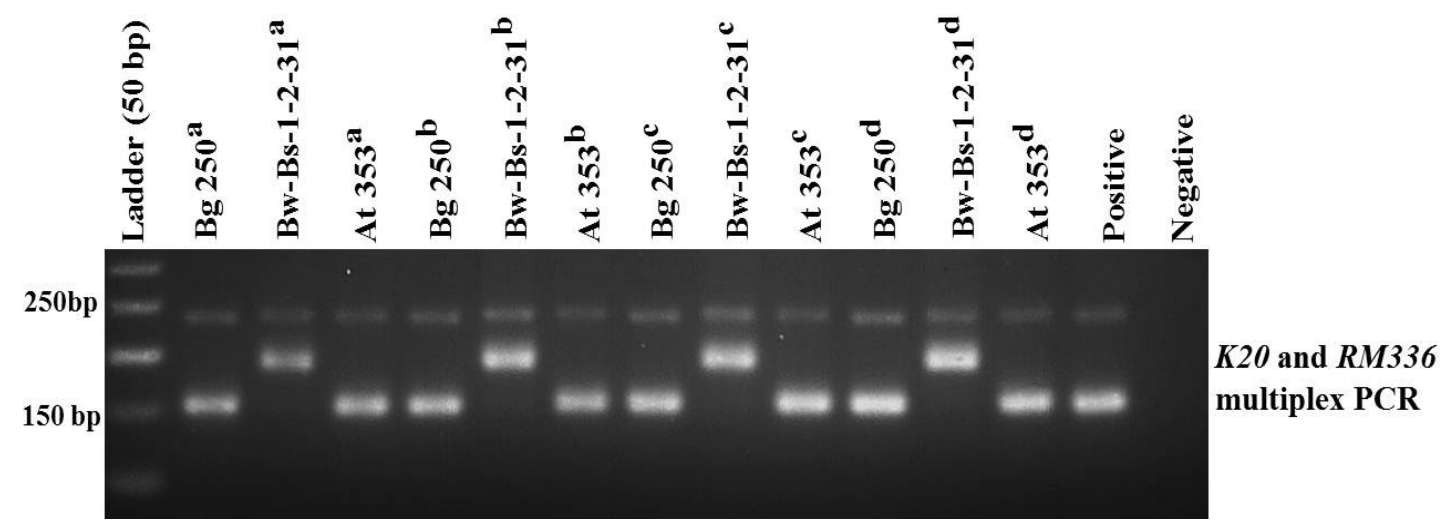

Figure 3: Agarose gel image of the multiplex PCR with $K 20$ and $R M 336$ markers (2.5\% agarose gel electrophoresis). The 50 bp ladder was used as the size standard. The key band sizes of the ladder are indicated on the left side. Names of the rice varieties/lines are given on the top. a: CTAB method, b: modified CTAB method, c: Promega kit, d: Qiagen kit.

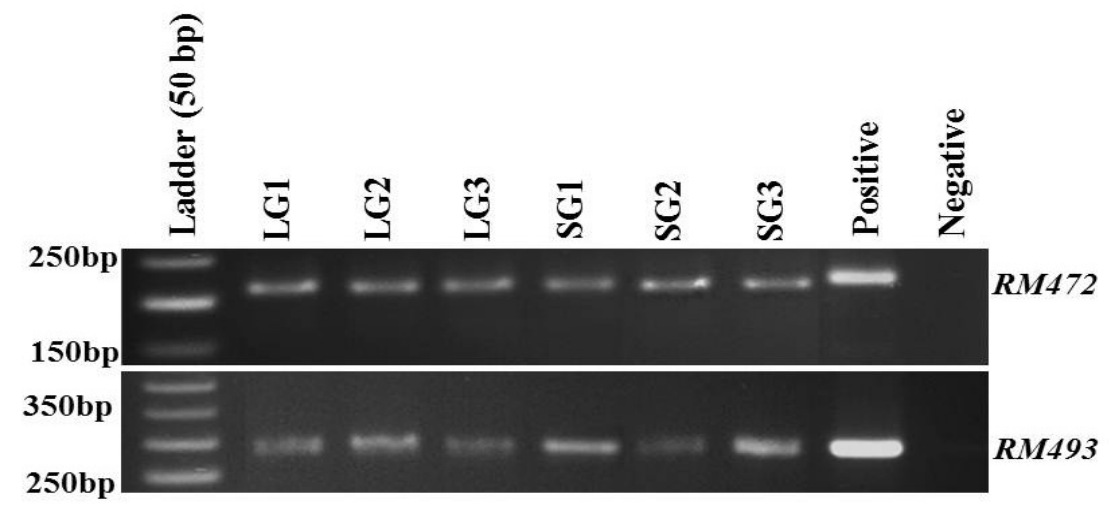

Figure 4: Composite agarose gel image of the simplex PCR with $R M 472$ and $R M 493$ markers (2.5 \% agarose gel electrophoresis). The names of the microsatellite markers are indicated on the right side of the Figure and the key band sizes of the ladder are indicated on the left side. The 50bp ladder was used as the size standard. Names of the market samples are given on the top. Three long grain (LG) (Nadu) and three short grain (SG) (Samba) samples were used for the analysis. The leaf DNA of the rice variety At 353 was used as the positive control in simplex PCR.

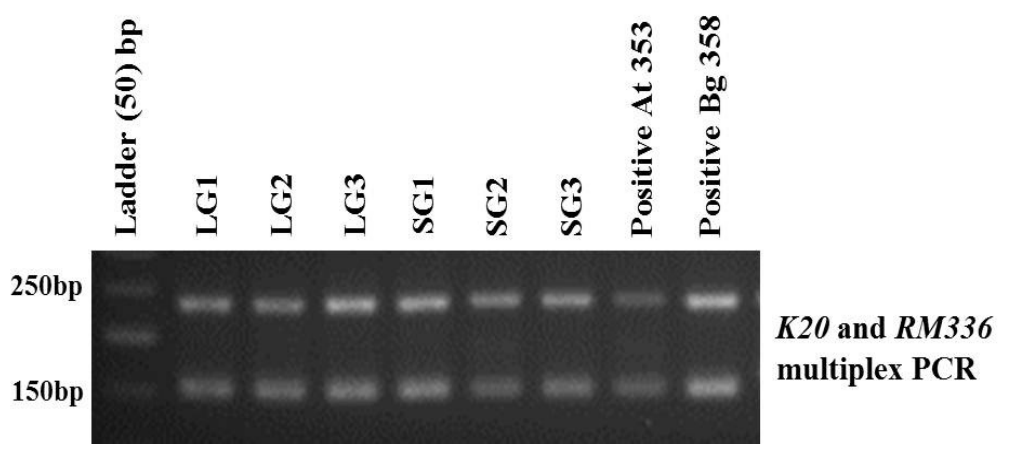

Figure 5: Agarose gel image of the multiplex PCR with K20 marker and RM336 markers (2.5\% agarose gel electrophoresis). The names of the microsatellite markers are indicated on the right side of the Figure and the key band sizes of the ladder are indicated on the left side. The 50bp ladder was used as the size standard. Names of the market samples are given on the top. Three long grain (LG) (Nadu) and three short grain (SG) (Samba) samples were used for the analysis. The leaf DNA of the rice varieties At 353 (LG type) and Bg 358 (SG type) were used as the positive controls in multiplex PCR.

\section{DISCUSSION}

Extraction of good quality DNA from rice caryopses is important for DNA fingerprinting of market samples to authenticate the varietal identity, detect hybrid purity and select required genotypes in MAS. Moreover, DNA fingerprinting of rice seeds would be required in germplasm conservation and management to unravel the mix-ups and defined core-collections. Although efficient DNA extraction procedures and commercial kits are readily available for rice leaves as the starting material, very few studies have been conducted to establish DNA fingerprinting protocols for rice caryopses and flour (Mutou et al., 2014). Two protocols have been established for DNA extraction from rice seeds by Duan et al., (2015) and from 
half-cut rice seeds of the varieties Nipponbare (O. sativa Japonica) and Junyou522 (O. sativa Indica) by Liang et al., (2016). However, none of these studies used common varieties found in Sri Lanka. The rice varieties/lines, Bg 250, Bw-Bs-1-2-31 and At 353 were especially selected for this study because $\mathrm{Bg} 250$ is a significant variety in Sri Lanka (covers $17.7 \%$ of the total cultivated crop), BwBs-1-2-31 is one of the selected lines for exporting because of its' premium cooking quality and At 353 is a common red rice variety grown in Sri Lanka because of the health concerns. Therefore, the present study possesses significant importance in establishing a sound protocol for DNA extraction from caryopses of the important rice varieties in Sri Lanka by comparing the commonly available methods for DNA isolation.

The chemical compound CTAB is used in DNA extraction to disrupt the cell membranes and EDTA is used as a chelating agent to trap $\mathrm{Mg}^{2+}$ ions to inhibit the DNAse activity. In the modified CTAB method, 0.5M EDTA was used in place of $20 \mathrm{mM}$ EDTA in general CTAB method to improve the efficiency of blocking $\mathrm{Mg}^{2+}$ ions to further reduce the DNAse activity. The $10 \mathrm{mM}$ concentration of Tris- $\mathrm{HCl}$ in general CTAB method was increased to $2 \mathrm{M}$ in modified CTAB method to obtain a higher degree of neutralization of negative charges to facilitate the DNA precipitation when isopropanol is present in the solution. To further improve the precipitation capacity, Na-acetate was added in the modified CTAB method as an enhancer molecule of the DNA precipitation (Dellaporta et al., 1983; Saghai-Maroof et al., 1984). The quality of DNA extracted from rice caryopses is always lowered by the presence of polysaccharides, polyphenols, tannins, alkaloids and proteins (Kasem et al., 2008). Out of these, polysaccharides make DNA samples sticky, thus vary the concentration of samples obtained in each pipetting event. The compound PVP was added as a significant alteration in the modified CTAB method to avoid the PCR inhibitory effects caused by the polyphenolic compounds. The addition of PVP has reported to yield sufficient amounts of polyphenolfree DNA samples that can be used for PCR and cloning purposes (Chaudhry et al., 1999; Zhang and Stewart, 2000). The proposed method could be used to extract DNA from 24 samples within three hours showing it's applicability for quick DNA diagnostic testing. Some of the caryopsis samples used were two years old and still able to provide good DNA samples highlighting the applicability of the proposed method for relatively aged samples. Usually within maximum of two years, harvested rice would be sold and consumed in the modern context. The random samples should be taken from caryopsis bulks (bags) using specifically designed probes and pooled together to ensure the uniformity of the samples for DNA extraction.

The simplex PCR was employed because some DNA markers cannot be combined in multiplex PCR for DNA fingerprinting. The multiplex PCR is essential in DNA fingerprinting exercises when conducted as two-marker reactions with one marker is providing a monomorphic band and the other marker is providing polymorphic bands. The inclusion of monomorphic marker in the multiplex PCR is really useful because it can display the false negatives in the analysis.

Although the DNA yield and the purity were variable among the methods used, the simplex and multiplex PCR attempts were able to produce clear, scorable bands in the agarose gels. The Qiagen kit yielded the significantly lowest DNA concentration which was not even detectable in agarose gel electrophoresis. However, it yielded the highest purity of DNA. For seeds of Zea mays hybrids, modified Qiagen method called Mericon extraction was found to be the most effective method for DNA extraction (AbdelLatif and Osman, 2017). In the present study, the modified CTAB method yielded the mean significantly highest DNA yield $(6196.67 \mu \mathrm{g} / \mathrm{ml}$, Table 2$)(P<0.05)$ and produced positive results in simplex and multiplex PCR, thus it can be considered as the practically best method for extracting DNA from rice caryopses for DNA fingerprinting. This is because with modified CTAB method, very high level of DNA yield is possible from the caryopsis samples and thereby many PCR can be conducted for any number of markers to set up the varietal authenticity to claim the PBR. The parboiled rice is highly preferred in many parts of Sri Lanka and Sri Lankan expatriate communities in foreign countries thus it is essential to prove the applicability of modified CTAB method to extract PCR amenable DNA from parboiled rice, especially for market samples and exporting bulks because rice varietal authenticity and the PBR have to be established for the samples circulating in marketing channels to claim the ownership and taxing purposes. The DNA extraction from parboiled rice is said to be difficult but the modified CTAB method used in the present study was able to extract amenable DNA for simplex and multiplex PCR. It is noteworthy to mention that, since the DNA concentration is very high in the samples extracted using modified CTAB method, a proper dilution to obtain 60-90ng of DNA for PCR must be carefully practiced. Otherwise too much DNA would inhibit the success of PCR. None of the DNA extraction methods/kits require liquid Nitrogen as a medium of grinding the caryopses and it is a distinct advantage because liquid Nitrogen is not easily available for the local laboratories in Sri Lanka. The present protocol of DNA extraction from rice caryopses can be readily used to extract DNA from the samples of export stocks to carry out the PCR based DNA fingerprinting.

\section{CONCLUSIONS}

The modified CTAB method produced the significantly the highest PCR amenable DNA yield from rice caryopses $(P<0.05)$ compared to general $\mathrm{CTAB}$ method and two commercial DNA extraction kits employed in the present study. The modified CTAB method can be readily used to isolate good quality DNA from parboiled rice caryopsis samples available in the market and the stocks prepared for exporting purpose. The RRDI/DOA can employ this method to extract DNA for a protocol on DNA fingerprinting to claim their PBR and rice varietal ownerships.

\section{ACKNOWLEDGEMENT}

The authors wish to acknowledge the financial assistance provide by the University of Peradeniya to carry out this research (Research Grant: URG/2016/59/S). The Director, 
Rice Research and Development Institute (RRDI), Bathalagoda, Sri Lanka is also acknowledged for providing necessary support to carry out this study.

\section{REFERENCES}

Abdel-Latif, A. and Osman, G. (2017). Comparison of three genomic DNA extraction methods to obtain high DNA quality from maize. Plant Methods. 13(1):DOI 10.1186/s13007-016-0152-4.

Bhat, K.V. (2001). DNA fingerprinting and cultivar identification. National Research Centre on DNA fingerprinting, N. B. P.G. R, New Delhi, Pp. 101-109.

Chaudhry, B., Yasmeen, A., Husnain, T. and Riazuddin S. (1999). Mini-scale genomic DNA extraction from cotton. Plant Molecular Biology Reporter. 17:1-7.

Chin, J. H., Lu. X., Haefele, H., Gamuyao, R., Ismail, A.M., Heuer, S. and Wissuwa, M. (2010). Development and application of gene-based markers for the major rice QTL Phosphorus uptake 1. Theoretical and Applied Genetics. 120:1073-1086.

Dellaporta, S.L., Wood, J. and Hicks, J.B. (1983). A plant DNA mini preparation: Version II.Plant Molecular Biology Reporter 1:19-21.

Disna,A.P.P. (2017). Export Potential for Export Agriculture Crops (EAC), Department of Export Agriculture, Available from: httphttp://www.ips.lk/wp-content/ uploads/2017/09/Disna IPS-Export-promotion.pdf. (18 ${ }^{\text {th }}$ February 2018).

Doyle, J.J. and Doyle, J.L. (1990). Isolation of plant DNA from fresh tissue. Focus. 12:13-15.

Duan, Y.B., Zhao, F.L., Chen, H.D., Li, H., Ni, D.H., Wei, P.C., Sheng, W., Teng, J.T., Zhang, A.M. and Xue,J.P. (2015). A simplified genomic DNA extraction protocol for pre-germination genotyping in rice. Genetics and Molecular Research. 14 (2): 6369-6375.

Kang, H., Cho, Y., Yoon, U. and Eun, M. (1998). A rapid DNA extraction method for RFLP and PCR analysis from single dry seed. Plant Molecular Biology Report. (16): $1-9$.

Kasem, S., Rice, N. and Henry, R. (2008). DNA extraction from plant tissue. Plant genotyping II: SNP technology, Henry, R.J. (Ed.), CAB International, Wallingford, UK, Pp 219-271.

Li, L., Zhang, Q. and Huang, D. (2014). A Review of Imaging Techniques for Plant Phenotyping. Sensors. 14:20078-20111.

Liang, H., Deng, Y., Wang, C. and Xu, X. (2016). A high-throughput DNA extraction method from rice seeds, Biotechnology \& Biotechnological Equipment. 30(1):32-35.

Muthayya, S., Hall, J., Bagriansky, J., Sugimoto, J., Gundry, D., Matthias, D., Prigge, S., Hindle, P., MoenchPfanner, R. and Maberly, G. (2012). Rice fortification: an emerging opportunity to contribute to the elimination of vitamin and mineral deficiency worldwide.Food Nutrition Bulletin. 33(4):296-307.

Mutou, C., Tanaka, K. and Ishikawa, R. (2014). DNA Extraction from Rice Endosperm (Including a Protocol for Extraction of DNA from Ancient Seed Samples) Henry, R.J. and Furtado A. (Eds.), Cereal Genomics:
Methods and Protocols, Methods in Molecular Biology Springer Science+Business Media New York 1099, DOI 10.1007/978-1-62703-715-0_2.

Pourabed, E., Noushabadi, M.R.J, Jamali, S.H., Alipour, N.M., Zareyan, A. and Sadeghi, L. (2015). Identification and DUS testing of rice varieties through microsatellite markers. International Journal of Plant Genomics. 2:17.

Rice Research and development Institute (RRDI) (2018). Rice Cultivation. Available from: http:// www.doa.gov.1k/rrdi/index.php?option $=\mathrm{com}$ sppagebuilder\&view=page\&id=42\&lang=en (accessed on $12^{\text {th }}$ March 2018).

Saghai-Maroof, M.A., Soliman, K.M., Jorgensen, R.A. and Allard, R.W. (1984). Ribosomal DNA spacer length polymorphism in barley: Mendelian inheritance, chromosomal location and population dynamics. Proceedings of the National Academy of Sciences of the United States of America.81:8014-8018.

Sambrook, J. and Russell, D.W. (2001). Molecular Cloning, a Laboratory Manual. Cold Spring Harbor Laboratory Press, Cold Spring Harbor, Pp 2-5.

Sarwat, M., Negi, M., Lakshmikumaran, M. and Tyagi, A. (2006). A standardized protocol for genomic DNA isolation from Terminalia arjuna for genetic diversity analysis. Electron Journal of Biotechnology. 9:pp.8691.

Selvaraj, C.I., Nagarajan, P., Thiyagarajan, K., Bharathi, M. and Rabindran, R. (2011). Identification of Microsatellite (SSR) and RAPD Markers Linked to Rice Blast Disease Resistance gene in Rice (Oryza sativa L.). African Journal of Biotechnology. 10(17): 3301-3321.

Senguttuvel, P., Raveendran, M., Vijayalakshmi, C., Thiyagarajan, K., Kannan Bapu J.R. and Viraktamath, B.C. (2010). Molecular Mechanism of Salt Tolerance for Genetic Diversity Analysed in Association with $\mathrm{Na}^{+}$/ $\mathrm{K}^{+}$Ratio through SSR Markers in Rice (Oryza sativa L.) International Journal of Agricultural Research 5:708-719.

Temnykh. S., Park, W.D., Ayres, N., Cartinhour, S., Hauck, N., Lipovich, L., Cho, Y.G., Ishii, T. and McCouch, S.R. (2000). Mapping and genome organization of microsatellite sequences in rice (Oryza sativa L.). Theoretical and Applied Genetics. 100(5):697-712.

Xin, Z., Velten, J., Oliver, M. and Burke, J. (2003). Highthroughput DNA extraction method suitable for PCR. Biotechniques. 34:820-826.

Zhang, J. and Stewart, J.M. (2000) Economical and rapid method for extracting cotton genomic DNA. Journal of Cotton Science. 4(3):193-201. 